\title{
Invasive red king crab affects lumpsucker recruitment by egg consumption
}

\author{
Nina Mikkelsen*, Torstein Pedersen \\ Department of Arctic \& Marine Biology, Faculty of Biosciences, Fisheries \& Economics, University of Tromsø, \\ 9037 Tromsø, Norway
}

\begin{abstract}
The invasive red king crab Paralithodes camtschaticus preys on lumpsucker Cyclopterus lumpus eggs. We tested the hypothesis this egg consumption may hamper the recruitment of lumpsucker. Methods applied included field work, laboratory experiments and modelling of egg consumption. Crabs were sampled and feeding behaviour was studied by means of a remotely operated vehicle and SCUBA divers in a field survey carried out in Varanger Fjord, Norway, in 2003. Laboratory experiments were carried out in 2006 to study the digestion of lumpsucker eggs by red king crabs, and a stomach evacuation model was fitted to the experimental data. Using data from the field and laboratory studies, an egg consumption model was used to quantify the amount of lumpsucker eggs consumed by king crabs in Varanger Fjord. The uncertainty in model input data was assessed using a Monte Carlo simulation. Sex or sampling area did not significantly affect egg predation. A total of $7.9 \%$ of all crab stomachs contained an average of 20 lumpsucker eggs, but the number of eggs per stomach varied widely. The average time required to evacuate lumpsucker eggs at $6^{\circ} \mathrm{C}$ in the laboratory experiment was $\sim 10 \mathrm{~h}$. In 2003, king crabs in Varanger Fjord consumed lumpsucker roe equivalent to approximately one-third of commercial catches during the same period. Red king crab predation on lumpsucker eggs may hamper lumpsucker recruitment in northern Norwegian waters.
\end{abstract}

KEY WORDS: Nonindigenous species $\cdot$ Paralithodes camtschaticus $\cdot$ Recruitment $\cdot$ Fish egg predation $\cdot$ Decapod digestion $\cdot$ Individual specialisation

\section{INTRODUCTION}

Most invasive predators are generalists (Park 2004), and once established, they may affect a wide range of prey species without producing a high risk of extirpation (Munoz et al. 2011). However, predation by alien species can have significant economic consequences, and this is an important rationale behind the growing interest in invasive species (Pimentel et al. 2000, Molnar et al. 2008). The red king crab Paralithodes camtschaticus, a generalist feeding decapod (Britayev et al. 2010), was introduced to the Barents Sea (Murmansk Fjord, Russia) by Russian scientists through several releases during the 1960s, with the intention of establishing a new fishery (Orlov \& Karpevich 1965, Orlov \& Ivanov 1978). Since the stock became established in the late 1970 s, it has become invasive and spread widely. It is now abundant throughout the southern Barents Sea, from coastal waters near Kolguyev Island $\left(69^{\circ} 01^{\prime} \mathrm{N}\right.$, $49^{\circ} 22^{\prime} \mathrm{E}$ ) in the east and along the coast of northern Norway to Sørøya $\left(70^{\circ} 35^{\prime} \mathrm{N}, 22^{\circ} 44^{\prime} \mathrm{E}\right)$ in the west (Britayev et al. 2010). Varanger Fjord was the first Norwegian fjord invaded by king crabs, which were regarded as abundant there in the 1990s. In spite of the growing interest in invasive species in general, 
very few attempts have been made to assess the impact of red king crabs on populations of native species and communities in and around the Barents Sea (Britayev et al. 2010).

The red king crab displays versatile feeding behaviour in these new areas (Sundet et al. 2000, Britayev et al. 2010, Oug et al. 2010), as well as in its native area in the north Pacific (Jewett \& Feder 1982). The most frequent prey species identified from stomach analysis of red king crab in Varanger Fjord are bivalves and polychaetes, in addition to algae, gastropods, several classes of echinoderms and some fish (Sundet et al. 2000, Haugan 2004). The red king crab breaks up its food with its chelae when necessary, making identification of prey difficult (McLaughlin \& Hebard 1961). Consumption of soft tissue may be underestimated in field studies (Sardà \& Valladares 1990) and this might introduce bias towards calcified and hard prey items, as these are more frequently recorded in crab stomachs. However, fish eggs have been found in crab stomachs (Sundet et al. 2000, Anisimova et al. 2005), and crabs have been seen feeding on eggs of lumpsucker Cyclopterus lumpus (Sokolov \& Milyutin 2006). The lumpsucker is not present in the native area of king crab, but it is found on both sides of the North Atlantic Ocean in temperate to cold waters (Davenport 1985, Kudryavtseva \& Karamushko 2002, Vasconcelos et al. 2004). During most of the year, the lumpsucker inhabits semi-pelagic offshore areas (Blacker 1983, Davenport 1985, Holst 1993), but in spring it migrates inshore to spawn in shallow water and sub-littoral areas on rocky bottoms among beds of Fucus spp. and Laminaria spp. macroalgae (Zhitenev 1970, Davenport 1985).

The lumpsucker is fished commercially for its high-value roe, and in 2008, the Norwegian catch amounted to $675 \mathrm{t}$ of roe, which had a first-hand value of NOK 18.9 million (Sunnanå 2009). Following a serious decline in the 1990s, the Norwegian lumpsucker stock was recently estimated to be at a historically low level, and is assumed to be suffering from weak recruitment (Sunnanå 2011). The reduction in abundance has been associated with overexploitation (Albert et al. 2002). It was also suggested that king crabs may displace lumpsuckers from their spawning sites (Kudryavtseva \& Karamushko 2002), as the adult crabs migrate to shallow areas in spring to moult and spawn (Sundet \& Hjelseth 2010).

Lumpsucker eggs are exposed to predation by king crabs in Varanger Fjord during the spring and summer season as lumpsuckers are demersal batch spawners (Zhitenev 1970, Collins 1976, Goulet et al. 1986) and egg incubation time ranges from 6 to
10 wk (Collins 1978, Davenport 1985, Goulet \& Green 1988). Spent females leave the spawning site, while the males stay behind and provide parental care until the eggs hatch (Cox \& Anderson 1922, Zhitenev 1970). The paternal guardianship includes aeration of the eggs and protection by removal and displacement of predators (Zhitenev 1970, Goulet et al. 1986, Goulet \& Green 1988). Invertebrate predators such as sea urchins Strongylocentrotus droebachiensis and periwinkles Littorina spp. are removed, while single fish predators are chased away by the guardian male (Goulet et al. 1986).

Predator stomach analysis and prey consumption models are employed to estimate the effects of predators on prey mortality and recruitment (Bax 1998). To estimate daily ration from stomach analysis, gastric evacuation rates are needed; most models were developed for fish (Eggers 1977, Elliott \& Persson 1978, Eggers 1979), but some have also been applied to decapod crustaceans (Maynou \& Cartes 1997, Cristo \& Castro 2005). Gastric evacuation is affected by temperature (dos Santos \& Jobling 1991, Wlodarczyk et al. 1992), prey type (Sardà \& Valladares 1990, Waddington 2008), predator size (Jobling 1981, Britayev et al. 2010) and meal size (Bromley 1994). Exponential decay functions have been used to estimate gastric evacuation rates of crustaceans (Hill 1976, Sardà \& Valladares 1990, Cristo 2001), and Pavlova (2009) used Bajkov's feeding model (Bajkov 1935), which assumes a linear gastric evacuation function to estimate prey consumption of red king crab in the Barents Sea. An alternative approach for estimating daily rations uses data on average stomach content and the integral of the gastric evacuation function (Olson \& Boggs 1986), which allows the use of a variety of evacuation functions.

The aim of this study was to examine the magnitude of lumpsucker egg consumption by the invasive red king crab in Varanger Fjord, Norway. We tested the hypotheses that (1) the parental care provided by the male lumpsucker is not sufficient to prevent egg predation by the red king crab (i.e. the crab is able to chase away the egg-guarding lumpsucker and feed on its eggs), (2) predation on fish eggs by the red king crab is affected by sex or spawning area of the lumpsucker, and finally, (3) consumption of eggs by the red king crab hampers the recruitment of lumpsucker.

Feeding behaviour of red king crab in field was studied by video recordings, and crabs for stomach analysis were collected by divers. A laboratory experiment was conducted to estimate the stomach evacuation rate of lumpsucker eggs by king crabs. 


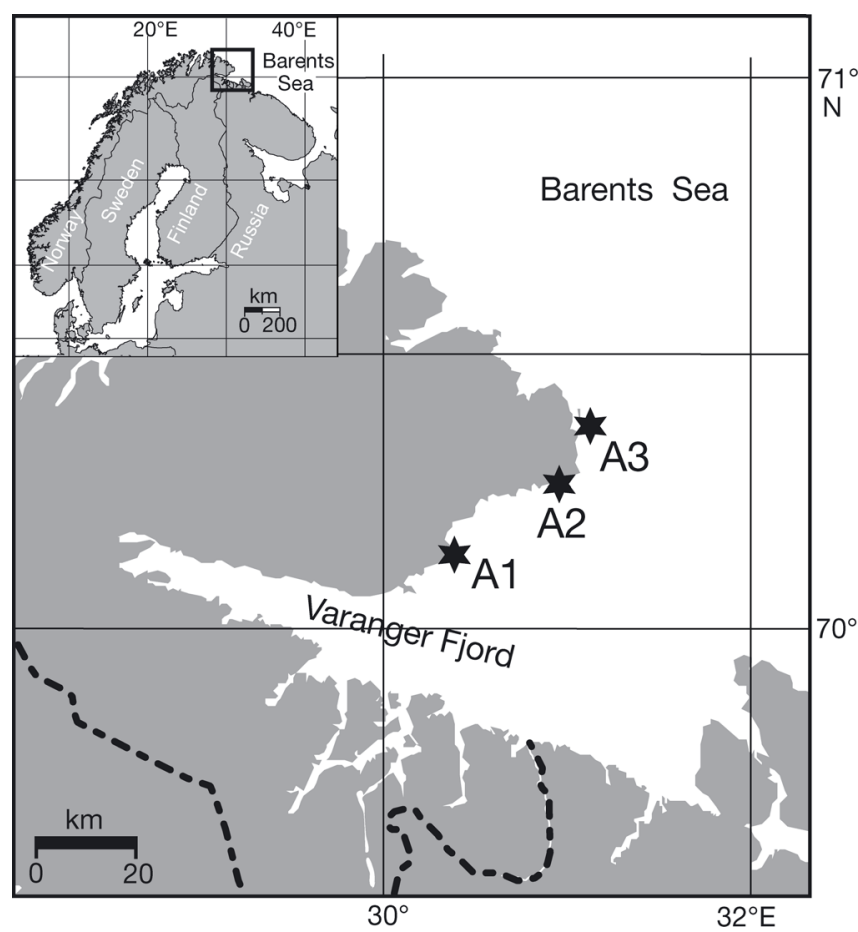

Fig. 1. Study area in Varanger Fjord, northern Norway, Barents Sea, showing lumpsucker spawning grounds. A1: Ekkerøy; A2: Kiberg; A3: Blodskyttodden

Finally, Monte Carlo simulations were applied to estimate egg consumption, taking into account the uncertainty in input parameters. To the best of our knowledge, this is the first estimate of consumption of guarded lumpsucker eggs by a decapod.

\section{MATERIALS AND METHODS}

\section{Study sites}

Data were collected during a survey using the commercial fishing vessel MS 'Leif Roald' in April and May 2003. Sampling was carried out at 3 lumpsucker spawning grounds (A1: Ekkerøy; A2: Kiberg; A3: Blodskyttodden) on the outer coast of Varanger Fjord (Fig. 1) which had the highest abundance of red king crab in 2003, and was the first Norwegian fjord invaded by the crab. The distribution of red king crab overlaps the distribution of spawning lumpsucker during spring and early summer. The lumpfish spawning grounds at depths $<30 \mathrm{~m}$ were selected based on knowledge of local fishermen. The average sea temperature in the sampling area was $3.4^{\circ} \mathrm{C}$. Site A3, which is an exposed area, is located at the entrance of the fjord, while the other 2 locations are situated in more sheltered areas on the northwest side of the fjord. All areas were suitable for SCUBA diving and for operating a remotely operated vehicle (ROV).

\section{Feeding behaviour}

Video recordings were made at rocky bottom habitat by the ROV and divers to determine whether the red king crab is able to chase away the egg-guarding lumpsucker and feed on its eggs. The ROV sailed 12 transects each over 0.3 to 2.6 nautical miles. Changing bottom topography prevented standardized transect distances. A total transect distance of 14.3 nautical miles was sailed along the shore at depths between 10 and $30 \mathrm{~m}$. The ROV was an Offshore Hyball 16 (Hydrovision) with a meridian view port that allowed the internally mounted colour camera to tilt and pan through $360^{\circ}$. Four thrusters provided motive power and a $300 \mathrm{~m}$ cable enabled us to search the area as the vessel maintained a speed of 0.2 to 0.3 knots at a depth $1-2 \mathrm{~m}$ above the seabed. In total, $127 \mathrm{~h}$ of video were recorded by the ROV, and $1 \mathrm{~h}$ was recorded by divers. All video recordings were analysed at the video laboratory facilities at the Institute of Marine Research (IMR) in Tromsø.

\section{Predation in the field}

The ROV was also used to detect sites where red king crabs were abundant at lumpfish spawning sites that were accessible (<30 m depth) for crab sampling by SCUBA diving. Due to the high current speed at Site A3, it was only possible to dive for $<30 \mathrm{~min}$ at high tide. We performed 19 dives in daylight at depths from 19 to $30 \mathrm{~m}$.

We attempted to sample both males and females in all areas to test for the effects of sex and area. A total of 127 red king crabs with carapace length (CL) $>70 \mathrm{~mm}$ were sampled (Fig. 2) during the diving time available $(16.5 \mathrm{~h})$. This size group was chosen because the population abundance estimate in Varanger Fjord does not include small crabs (CL $<70 \mathrm{~mm}$ ). CL was measured to the nearest $\mathrm{mm}$, while sex and carapace age were determined according to standard procedures (Donaldson \& Byersdorfer 2005); shell age classification was divided into 6 stages which reflect the approximate time since the last moult. Crabs were killed by cutting the isthmus before lifting the carapace, which revealed the stomach attached to the carapace. Stomachs were re- 


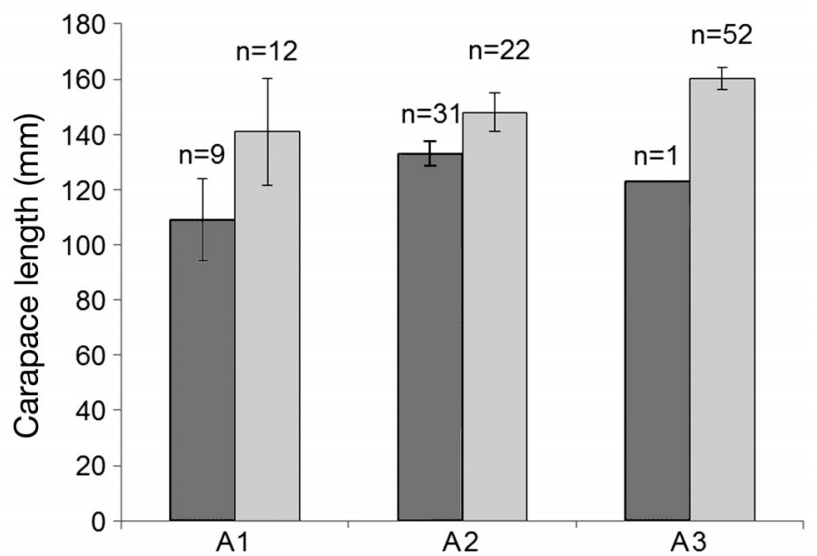

Fig. 2. Paralithodes camtschaticus. Carapace length (mean \pm $95 \% \mathrm{CI}$ ) of female ( $\square$ ) and male ( $\square$ ) crabs sampled for stomach analysis in 3 areas of Varanger Fjord, Norway, in 2003

moved and preserved in $4 \%$ buffered formaldehyde $(n=97)$ or Neofix ${ }^{\circledR}(n=30)$ for analysis. Neofix ${ }^{\circledR}$ is an ethanol-based fixative (Merck). One clutch of lumpsucker eggs was collected to facilitate later identification in stomach analysis. The clutch was kept at $4^{\circ} \mathrm{C}$ in natural seawater that was changed daily.

Stomachs preserved in buffered formaldehyde were kept in running fresh water for $24 \mathrm{~h}$ before analysis, while those preserved in Neofix ${ }^{\circledR}$ were rinsed off with fresh water and immediately analysed. Eggs with an unbroken chorion were counted and identified by characteristics such as shape, egg diameter, oil droplets and pigmentation, as described by Breder \& Rosen (1966) and Russell (1976), and compared to the lumpsucker egg sample. Other prey items were not identified.

The frequency of occurrence (FO) of eggs in king crab stomachs was calculated. As well as stomachs containing food, empty stomachs were included in the analysis, since they reflect the natural feeding state of the population. The effects of sex and sampling area on FO were studied. 95\% confidence intervals (CI) of the mean number of eggs per stomach were calculated by bootstrapping. For all tests, $\alpha$ $<0.05$ was considered significant. All analyses were performed SYSTAT version 13 (SYSTAT Software International).

\section{Consumption model}

A consumption model was employed to estimate the total annual consumption of lumpsucker eggs by king crabs (>70 mm CL) in Varanger Fjord. The consumption model approach was described by Olson \&
Boggs (1986). King crabs were assumed to feed continuously, and consumption of eggs $(C)$ was estimated by the equation:

$$
C=\frac{W}{A} \cdot 24 \cdot E \cdot T \cdot P \cdot 10^{-6}
$$

where $W$ is the mean number of eggs in stomachs sampled in the field in 2003, $A$ is the average time (h) required to evacuate lumpsucker eggs (Olson \& Boggs 1986), $E$ is egg weight $(\mathrm{g}), T$ is the time eggs are available for predation (d) and $P$ is the total number of king crabs (>70 mm CL) in Varanger Fjord in 2003. The factor $10^{-6}$ converts $g$ to $t$ so that $C$ is in $t$. The individual daily ration in terms of number of eggs consumed per day is given by $(W / A) \times 24$.

\section{Stomach evacuation rate experiment}

King crabs were collected during a survey with RV 'Johan Ruud' in April 2006. Crabs with missing limbs were excluded from the experiment. To obtain 1 datum for each hour during the $24 \mathrm{~h}$ expected digestion time (Pavlova 2009), 24 mature male crabs were captured at depths of 54 to $207 \mathrm{~m}$ by Agassiz trawl (bottom trawl) off the coast of Finnmark (approx. $\left.70^{\circ} 57^{\prime \prime} \mathrm{N}, 29^{\circ} \mathrm{E}\right)$. Due to the risk of spreading the species, female crabs must not be used in experimental work at the research facilities at the University of Tromsø, where the crab is not established in nature at present. The crabs were kept in dark containers with running seawater during transportation to the university. Lumpsucker eggs guarded by a male were collected by a SCUBA diver at a depth of $2 \mathrm{~m}$ at

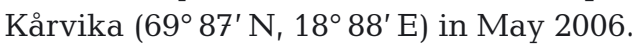

During the acclimation period that lasted $4 \mathrm{wk}$, similar to earlier experiments with red king crab (Jørgensen \& Primicerio 2007), the crabs were kept in 4 square $1 \times 1 \mathrm{~m}$ stocking tanks with $500 \mathrm{l}$ natural seawater, $21 \mathrm{~min}^{-1}$ water flow, constant light and a water temperature between $5^{\circ} \mathrm{C}$ and $6^{\circ} \mathrm{C}$. Dead spent capelin is a common prey of the red king crab in the field during spring, and all crabs were fed dead capelin and lumpsucker eggs. Only actively feeding crabs $(n=17)$ were used in the experiment (Table 1). During the experiment the temperature was $6^{\circ} \mathrm{C}$. The crabs were starved for $24 \mathrm{~h}$ before they were transferred to the individual experimental tanks, which were identical to the stocking tanks. Starvation continued for a further $24 \mathrm{~h}$ while the crabs were settling in the individual tanks. The experiment ran from 23 May until 12 June, 2006. 
Table 1. Cyclopterus lumpus and Paralithodes camtschaticus. Consumption of lumpsucker eggs by male red king crabs in stomach evacuation experiment in 2006. Crab weight and carapace length are listed. Prey is listed in numbers and wet weight of fed and eaten eggs and is also expressed as percentage of body weight. The percentage of eggs offered but not eaten is listed by spilling rate (\%). Individual egg weight was estimated from 3 samples of the egg batch used in the stomach evacuation experiment

\begin{tabular}{|lcc|}
\hline $\begin{array}{l}\text { Experimental animals } \\
\text { and prey }\end{array}$ & Range & Average \pm SD \\
\hline Red king crab (n= 17) & & \\
Weight (g) & $939-3123$ & $1724 \pm 681$ \\
Carapace length (mm) & $113-166$ & $136 \pm 17$ \\
Offered lumpsucker eggs & & \\
Individual egg weight (g) & & $6.13 \times 10^{-3}$ \\
& & $\pm 5.40 \times 10^{-5}$ \\
Weight (g) & $2.5-10.0$ & $4.56 \pm 2.50$ \\
Weight (\% body weight) & $0.15-0.53$ & $0.27 \pm 0.08$ \\
Number of eggs & $407-1630$ & $744 \pm 335$ \\
Consumed lumpsucker eggs & & \\
Weight (g) & $1.99-6.99$ & $4.09 \pm 1.37$ \\
Weight (\% body weight) & $0.13-0.41$ & $0.26 \pm 0.09$ \\
Number of eggs & $391-1139$ & $643 \pm 183$ \\
Spilling rate (\% of offered) & $0.7-61.3$ & $8.4 \pm 14.45$ \\
\hline
\end{tabular}

Crabs were fed meals of eggs that were adjusted to their body weight (average $0.27 \%$ of BW), and uneaten eggs were removed from the tank after $\sim 20$ min. Crabs which did not consume their prey within 20 min were transferred back to the storage tank. The experiment was repeated following the same procedure, but if the crabs failed to feed on the second trial they were discarded as experimental animals. Average feeding time was $10 \mathrm{~min}$ for egg rations ranging from 2.5-10.0 g (Table 1). Given the average egg weight of $6.13 \mathrm{mg}$ (Table 1), the number of eggs fed ranged from 407 to 1630 . The meal size of $0.27 \%$ of predator weight is comparable to previous estimates of daily ration of red king crab in the field of 0.30 to $2 \%$ of body weight (Tarverdieva 1978, Gudimov et al. 2003). Crabs were killed hourly, from 1 to $17 \mathrm{~h}$ after the meal following the same procedure as described above. Fish eggs with an unbroken chorion were visually identified and counted.

The uneaten eggs were weighed and counted, so the number of eggs eaten could be estimated, and spillage of prey was calculated as a percentage of offered prey. Empty eggs with a broken chorion and no content were not counted and were classified as an initial loss. An ogive stomach evacuation model, $f(t)$, was fitted to the estimates of proportion of undigested eggs (undigested eggs:number of eggs eaten) at a given time $t$, where the initial loss of prey during ingestion is given by the parameter $a$. In this study, visual observations showed that initial loss of prey occurred, as some eggs were punctured during feeding and egg contents and chorion were lost without being recovered from the tank. The starting value for initial loss a was based on literature values from Hill (1976) and Cristo (2001). The slope of the curve is defined by $b$, and the half-time of prey in the stomach is given by $c$. Starting values for $b$ and $c$ were based on interpretation of experimental data.

$$
f(t)=(1-a) \cdot \frac{1}{1+e^{b(-c+t)}}
$$

The model was fitted by nonlinear regression in SYSTAT. The model fit was evaluated by the adjusted $\mathrm{r}^{2}$, the significance of model parameters, asymptotic correlation matrix of parameters and residual analysis. Statistical outliers were defined as estimates with values more than 3 times the SD of the mean of the residuals. Effects of digestion time, crab weight and meal size (number of eggs consumed) on the model fit were identified.

The mean time $A(\mathrm{~h})$ required to evacuate lumpsucker eggs from the stomach was estimated in accordance with Olson \& Boggs (1986), by integrating $f(t)$ numerically, using the equation:

$$
A=\int f(t) \mathrm{d} t
$$

The estimate of $A$ and its SE were used in the following Monte Carlo (MC) estimation of consumption.

\section{Estimating consumption}

Values for input data for the consumption model (Eq. 1) were randomly selected from distributions that are believed to adequately describe the uncertainty in the data (Table 2). MC simulations were run, 1000 bootstrap replicates of stomach content from field data were generated, and mean stomach content $(W)$ was calculated for each bootstrap replicate and run of the MC simulation. Input values for digestion time (A), estimated by Eq. (3), were randomly selected from a normal distribution and the SD was set to the estimated SE.

The mean egg weight $(E)$ was randomly selected from a normal distribution following same procedure as for $A$. Input data for the mean and SD of $E$ (Table 3) were estimated by combining data from this study and from the literature (Zhitenev 1970), accessing the differences in egg weights between 
Table 2. Input data for Monte Carlo simulation of consumption of lumpsucker eggs by red king crab in Varanger Fjord. Values for input data were randomly selected from distributions that were believed to adequately describe the uncertainty in the input data; mean stomach content ( $W_{;}$no. of eggs), average gastric evacuation time $\left(A_{;} \mathrm{h}\right)$, egg weight $\left(E_{;} \mathrm{g}\right)$, egg incubation time $(T ; \mathrm{d})$ and population size of red king crab in Varanger Fjord 2003-2010 ( $P$; no. of individuals). Normally distributed variables noted as $\mathrm{N}$ (mean $\pm \mathrm{SD}$ )

\begin{tabular}{|c|c|c|}
\hline $\begin{array}{l}\text { Para- } \\
\text { meter }\end{array}$ & Distribution & Source \\
\hline$W$ & $\begin{array}{l}1000 \text { values from empirical } \\
\text { distribution }\end{array}$ & $\begin{array}{l}\text { Values generated by } 1000 \text { boots- } \\
\text { trapping replicates of stomach } \\
\text { content estimated from field data } \\
2003(\mathrm{n}=127)\end{array}$ \\
\hline$A$ & $A \sim \mathrm{N}(9.967 \pm 0.630)$ & $\begin{array}{l}A=\int f(t) \mathrm{d} t \text {, gastric evacuation } \\
\text { function fitted to experimental } \\
\text { data (Table } 4 \text { ). SD (estimated in } \\
\text { SYSTAT by FUNPAR) was set to SE }\end{array}$ \\
\hline E & $E \sim \mathrm{N}(0.006253 \pm 0.000886)$ & $\begin{array}{l}\text { Mean and SD of measurements } \\
\text { from experiment and Zhitenev } \\
(1970) \text { estimated by maximum } \\
\text { likelihood method and tested } \\
\text { for normality by Shapiro-Wilks } \\
\text { test }(p=0.32)\end{array}$ \\
\hline$T$ & Uniform $(\min .=72, \max .=124)$ & $\begin{array}{l}\text { Field observations (this study) } \\
\text { Fisheries statistic (Norwegian } \\
\text { Fishermen's Sales Organisation) } \\
\text { Davenport (1985) }\end{array}$ \\
\hline$P_{2003}$ & $P \sim \mathrm{N}(1001034 \pm 140145)$ & Supplied by the Institute \\
\hline$P_{2004}$ & $P \sim \mathrm{N}(1205790 \pm 217042)$ & of Marine Research, based on \\
\hline$P_{2005}$ & $P \sim \mathrm{N}(1231842 \pm 135503)$ & a trawl survey \\
\hline$P_{2006}$ & $P \sim \mathrm{N}(1346901 \pm 202035)$ & \\
\hline$P_{2007}$ & $P \sim \mathrm{N}(1564667 \pm 297287)$ & \\
\hline$P_{2008}$ & $P \sim \mathrm{N}(1368850 \pm 355901)$ & \\
\hline$P_{2009}$ & $P \sim \mathrm{N}(1361918 \pm 231526)$ & \\
\hline$P_{2010}$ & $P \sim \mathrm{N}(1195068 \pm 227063)$ & \\
\hline
\end{tabular}

batches and during the spawning season (Zhitenev 1970, Davenport 1985). All egg weight measurements in this study were from the same egg batch, while data from the literature were from different batches.

Table 3. Cyclopterus lumpus. Estimated weight of 3 samples of lumpsucker eggs from 1 egg batch in laboratory stomach evacuation experiment and from literature (Zhitenev 1970). Mean and SD (see Table 5) were calculated by the maximum likelihood method and the sample was tested for normality by the Shapiro-Wilks test $(W=0.88, \mathrm{p}=0.321$ )

\begin{tabular}{|lll|}
\hline Sample & Weight $(\mathrm{mg})$ & Source \\
\hline 1 & 6.182 & This study \\
2 & 6.075 & This study \\
3 & 6.144 & This study \\
4 & 7.813 & Zhitenev (1970) \\
5 & 5.051 & Zhitenev (1970) \\
\hline
\end{tabular}

The uncertainty in the duration of accessibility of eggs $(T)$ was incorporated by random sampling from a uniform distribution ranging from 72 to $124 \mathrm{~d}$. The minimum value was based on the assumption that a female spawns 3 batches at intervals of $6 \mathrm{~d}$, with an embryonic incubation time of 60 d. First spawning, based on our field observations, was on 24 April, and the last date of spawning was assumed to be on 5 July, the date when the lumpsucker fishery closes in Varanger Fjord. For the latest spawners, we assumed an egg incubation time of $40 \mathrm{~d}$ due to a rise in temperature during the summer.

Estimates of the total stock of red king crab (>70 mm CL) in Varanger Fjord $(P)$ in 2003 were supplied by the Institute of Marine Research (A. M. Hjelseth pers. comm.). These estimates were based on trawl surveys and swept area estimates. In every MC run, random values of red king crab population numbers in Varanger Fjord in 2003 were sampled from a normal distribution. In addition to estimation of egg consumption in 2003 (MC1), additional estimations were performed for the period from 2004 to 2010 (MC2), using a time series of red king crab population size from 2004 to 2010 supplied by the Institute of Marine Research, while all other input data were randomly sampled from the same distributions as described for MC1 above. To compare the effects of predation on egg mortality, consumption estimates (MC1 and MC2) were compared to lumpsucker roe landings from 2003 to 2010 in the same area, supplied by the Norwegian Fishermen's Sales Organisation (G. Johnsen pers. comm.).

All MC simulations of consumption estimates and CI were generated using PopTools version 3.2.3 in Excel 2010 (Hood 2010) (available at www.poptools. org). We estimated CIs using the percentile method on the 1000 resamples. The influence of the uncertainty in input parameters on the egg consumption estimates was evaluated by studying the significance of the correlation (Spearman rank correlation coefficient; $r_{s}$ ) between input values and MC estimates of consumption. 


\section{RESULTS}

\section{Feeding behaviour}

In general, the red king crabs did not seem to be disturbed by the ROV or divers while they were feeding. Some crabs walked away from the ROV, but they did not drop their prey. Some crabs searched the substrate by 'filtering'. One egg-guarding lumpsucker was unable to protect his eggs from a feeding red king crab that pushed the fish away with its leg (see supplementary video at www.int-res.com/articles/ suppl/m469p087_supp/). Due to dense aggregations, the total number of crabs could not be estimated, but 5 crabs were observed feeding on clumps of lumpsucker eggs that had become detached from the original egg clutch, and they all spilled a substantial proportion of eggs while feeding.

\section{Predation in the field}

The sample consisted of 86 males (mean CL = $154.4 \mathrm{~mm}$, range $=79-185 \mathrm{~mm}$ ) and 41 females (mean CL $=127.5 \mathrm{~mm}$, range $=82-184 \mathrm{~mm}$ ). All crabs were classified as recently moulted or new-shell pliable, a stage ranging from 2 to $8 \mathrm{wk}$ post-ecdysis. Egg identification in the stomach analysis was equal for samples fixed in Neofix ${ }^{\circledR}$ or $4 \%$ formaldehyde.

The frequency of occurrence of lumpsucker eggs in king crab stomachs did not differ significantly between females and males at any sampling site (Fig. 3, Fisher exact test; Site A1; p > 0.99, Site A2; $\mathrm{p}>0.99$, Site A3; p > 0.99), or between the 3 sites when data for both sexes were pooled (Fisher exact test; $p=0.31$ ). As there were no effects of sex or area, all individuals were pooled $(\mathrm{n}=127)$ for all

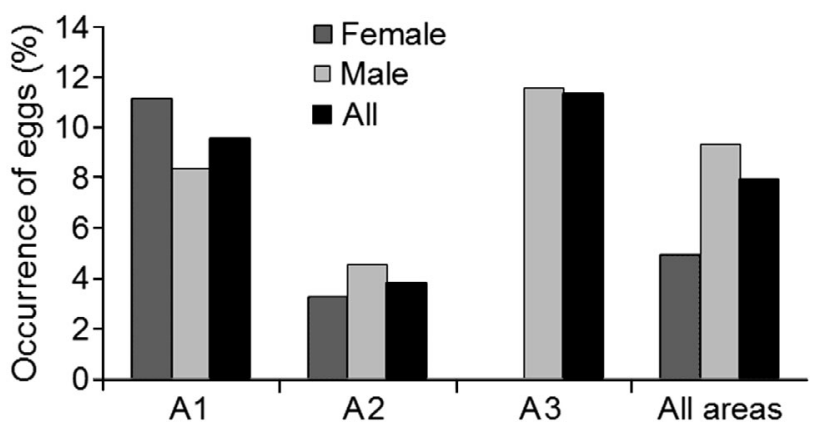

Fig. 3. Cyclopterus lumpus eggs and Paralithodes camtschaticus. Occurrence of consumed lumpsucker eggs in red king crab stomachs at 3 lumpsucker spawning sites in Varanger Fjord, Norway further analyses, giving a FO of $7.9 \%$. The number of eggs found in stomachs ranged from 0 to 1640 and the mean number of eggs per crab was estimated at 20 (95\% CI: 1, 52).

\section{Stomach evacuation rate}

Seventeen mature male crabs successfully completed the feeding experiment. All crabs seemed unstressed in the experimental tanks within $2 \mathrm{~h}$ after they were transferred from stocking tanks and appeared to be calm when the experiment started $24 \mathrm{~h}$ later. The crabs displayed different individual feeding behaviour. Some held the egg clump with their left cheliped, others with the maxillipeds while eating. The latter feeding technique was the fastest, but egg spillage was considerable with both techniques. On average, the crabs consumed $0.26 \%$ of their body weight (Table 1), and an average of $8.4 \%$ of the offered eggs remained uneaten and were removed from the bottom of the tank after $20 \mathrm{~min}$.

No lumpsucker eggs or egg remains could be found in stomachs $17 \mathrm{~h}$ after ingestion (Fig. 4). The estimated initial loss (a) was $17.3 \%$ of the eggs eaten (Table 4) and average time $(A)$ required to evacuate lumpsucker eggs was estimated at $9.97 \mathrm{~h}(95 \% \mathrm{CI}$ : 8.62, 11.32). All parameters of the stomach evacuation model were significantly different from zero (Table 4 ) and the adjusted $\mathrm{r}^{2}$ was 0.84 . The parameters were not highly correlated ( $a$ versus $b ; \mathrm{r}=$ 0.55 , a versus $c_{i} \mathrm{r}=0.59$ and $b$ versus $c_{i} \mathrm{r}=0.38$ ), underlining the statistical independence of the parameters and indicating that the model was not overparameterised. No statistical outliers were detected, and residuals were normally distributed (Lillefors test, $\mathrm{p}=0.29$ ) and displayed homogeneity of variance (chi-squared test, $\chi^{2}=16.21$, df $=16, p=0.88$ ). Residuals were not significantly correlated with crab weight $(r=0.45, p=0.07)$, digestion time $(r=-0.08$, $p=0.76)$ or meal size $(r=0.36, p=0.15)$.

\section{Consumption estimates}

The total annual consumption of lumpsucker eggs by red king crabs (>70 mm CL) in Varanger Fjord in 2003 was estimated at 30.7 t (95\% CI: 0.74, 89.3) and $7.9 \%$ of the same population was estimated to be feeding on these eggs (Table 5). The mean number of days eggs are available, calculated by resampling, was 98 (95\% CI: 73, 123), while the corresponding red king crab population size was 1002356 ind. (95\% 
CI: 725 242, 1277 892); these values were very close to the input values (Table 2). Input data for $W$ and egg consumption estimates were highly correlated $\left(r_{s}=0.93\right)$, showing that stomach input data were the main source of uncertainty, while all the other input parameters had a small input range and correlated only weakly with consumption estimates (Fig. 5).

The estimated consumption of lumpsucker roe by red king crabs in 2003 (MC1) was equivalent to approximately one-third of the landed roe in the same area in 2003 (Fig. 6b). Between 2004 and 2007, landings of roe declined to a minimum of $\sim 6 \mathrm{t}$ in 2007 (Fig. 6b). Simultaneously, consumption estimates (MC2) increased and were higher than roe landings both in 2006 and 2007, following the rise in the king crab population in Varanger Fjord (Fig 6a). This population peaked in 2007 at 1546667 ind. and the consumption of eggs in this year was estimated by MC2 at 45.9 t. After 2008, the estimated consumption declined following the decline in the red king crab population. At the same time, a 7 -fold increase was registered in roe landings from fisheries from 2007 to 2008 , followed by a steady rise in landings until the end of the time series.

\section{DISCUSSION}

We report the first estimates of lumpsucker egg consumption by the invasive red king crab in the North Atlantic. Most previous studies on potential effects of the crab in this area have focused on diet composition (Sundet et al. 2000), changes in density and size composition of sea urchins Strongylocentrotus droebachiensis (Gudimov et al. 2003, Pavlova 2008, 2009), effects on scallop beds (Jørgensen 2005, Jørgensen \& Primicerio 2007) and soft-bottom communities (Britayev et al. 2010, Oug et al. 2010). In a study on eggs of capelin Mallotus villosus in Canadian waters, an egg-feeding amphipod, Calliopius laeviusculus, accounted for 5 to $30 \%$ of annual egg losses (DeBlois \& Leggett 1993). The lack of estimates of lumpsucker spawning stock in Varanger Fjord makes it difficult to evaluate the effects of consumption and damage to eggs by the invasive red king crab.

When compared to catches from roe fisheries, the consumption of lumpsucker roe by red king crabs was substantial in some years. However, year to year fluctuations in roe landings (for the total stock of lumpsucker) also occurred in the late 1980s (Michalsen 2004), before the crab invaded important lumpsucker spawning grounds in Varanger Fjord. The

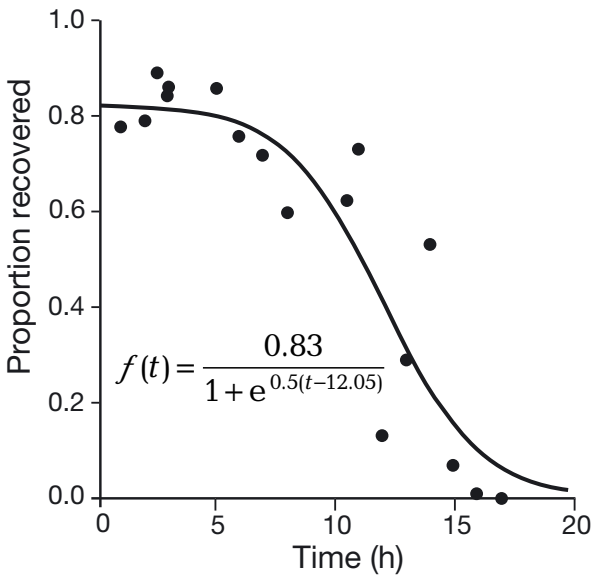

Fig. 4. Paralithodes camtschaticus. Stomach evacuation rate of red king crabs fed lumpsucker eggs at $6^{\circ} \mathrm{C}$. •: observed proportion of eggs left in stomach at given time. Line: ogive stomach evacuation model fitted to the observed proportion of stomach contents $f(t)$. The initial loss of eggs during feeding is $1-0.83$.

Table 4. Parameter estimates of stomach evacuation model $f(t)$ for lumpsucker eggs consumed by red king crabs, estimated by nonlinear regression. Initial loss is given by $a$, the slope of the curve by $b$ and the half-time of prey in the stomach by $\sim 95 \%$ confidence intervals and significance levels (p-value) of parameters (1-sample $t$-test). Average time required to evacuate an average proportion of meal $\left(A=\int f(t)\right.$ $\mathrm{d} t$ ) was calculated by numerical integration

\begin{tabular}{|lcccr|}
\hline \multirow{2}{*}{$\begin{array}{l}\text { Para- } \\
\text { meter }\end{array}$} & \multirow{2}{*}{$\begin{array}{c}\text { Esti- } \\
\text { mate }\end{array}$} & \multicolumn{2}{c}{$\begin{array}{c}\text { Confidence interval } \\
\text { Lower }\end{array}$} & Upper \\
\hline$a$ & 0.173 & 0.040 & 0.306 & 0.014 \\
$b$ & 0.495 & 0.119 & 0.870 & 0.013 \\
$C$ & 12.05 & 10.43 & 13.670 & $<0.001$ \\
$A$ & 9.967 & 8.615 & 11.318 & \\
\hline
\end{tabular}

Table 5. Average, SD and 95\% confidence intervals of input parameters for Monte Carlo simulation of consumption of lumpsucker eggs by red king crab: mean stomach content $(W)$, average gastric evacuation time $(A)$, egg weight $(E)$, egg incubation time $(T)$, population size of red king crab in Varanger Fjord $2003(P)$, frequency of occurrence of lumpsucker eggs in red king crab stomachs (FO) and annual egg consumption in $2003(C)$ calculated from 1000 resamples of input values

\begin{tabular}{|c|c|c|c|}
\hline \multirow[t]{2}{*}{ Parameter } & \multirow[t]{2}{*}{ Average \pm SD } & \multicolumn{2}{|c|}{ Confidence interval } \\
\hline & & Lower & Upper \\
\hline$W$ (no. of eggs) & $21 \pm 14$ & 1 & 53 \\
\hline$A(\mathrm{~h})$ & $9.97 \pm 0.63$ & 8.73 & 11.19 \\
\hline$E(\mathrm{mg})$ & $6.23 \pm 1.00$ & 4.31 & 8.20 \\
\hline$T(\mathrm{~d})$ & $98 \pm 15$ & 73 & 123 \\
\hline$P$ (no. of ind.) & $1002356 \pm 141623$ & 725242 & 1277892 \\
\hline $\mathrm{FO}(\%)$ & $7.9 \pm 2.4$ & 3.9 & 12.6 \\
\hline$C(\mathrm{t})$ & $30.7 \pm 23.2$ & 0.7 & 89.3 \\
\hline
\end{tabular}




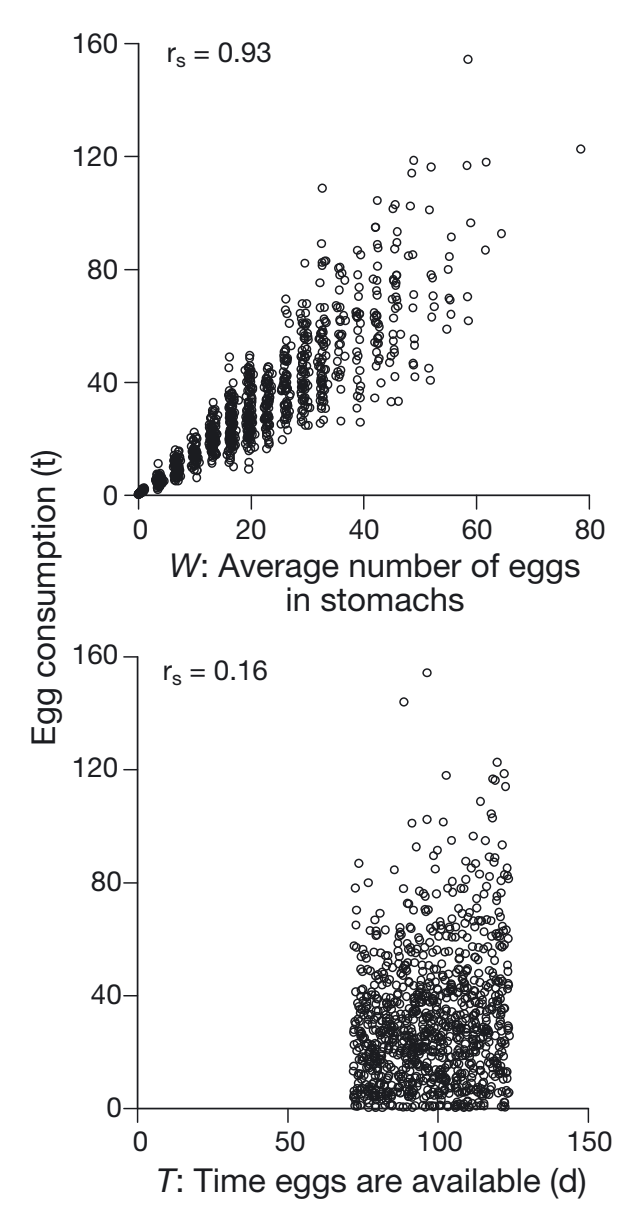

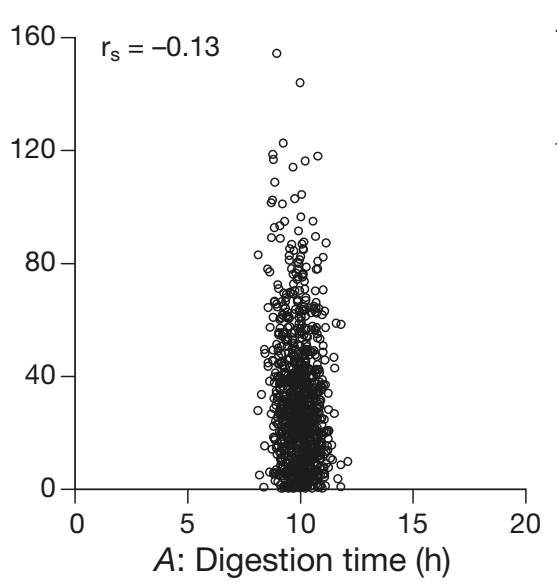

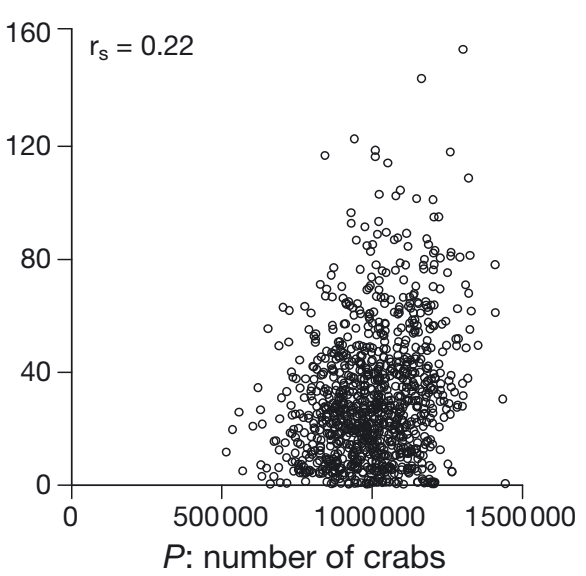

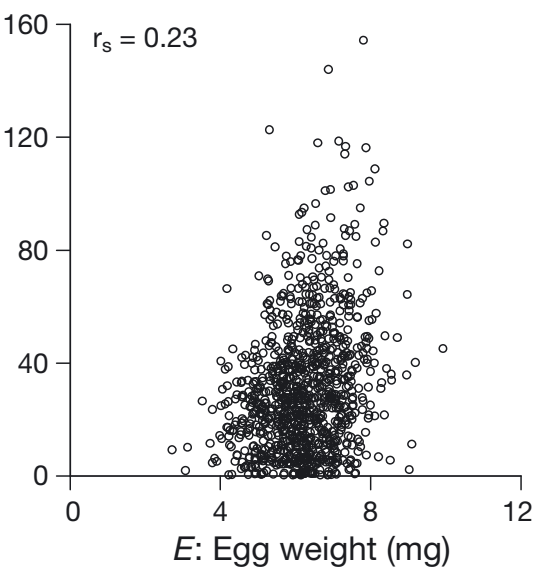

Fig. 5. Results of 1000 Monte Carlo simulations of consumption of lumpsucker eggs by red king $\mathrm{crab}_{\text {; }}$ average number of eggs $(W)$, digestion time $(A)$, egg weight $(E)$, time eggs are available $(T)$ and number of crabs $(P)$, plotted against consumption estimates of lumpsucker eggs by red king crabs in 2003, taking into account uncertainty in input data by sampling from probability distributions assumed to represent the input data. Spearman rank correlation coefficient is shown fishery depends largely on the market situation for roe and the number of participating vessels, but also weather conditions, especially since only small boats are used in the shallow areas (Sunnanå 2004), and has been considerably hindered by the prevalent red king crab since its invasion (Sunnanå 2006). The spawning stock and level of roe catches may be affected by recruitment failure, which can be caused by storms sweeping egg masses away from spawning sites and depositing them in the intertidal zone (M'Intosh 1886 as cited in Davenport 1985).

Since area and sex did not affect the frequency of occurrence of lumpsucker eggs in red king crab stomachs, the large variability in the number of eggs per stomach suggests that the large confidence interval around the estimated consumption was mainly caused by the range of egg numbers found in stomachs. All other input parameters in the Monte Carlo estimation had smaller ranges and much less effect on estimated consumption. Also, estimates of consumption are affected by the average stomach evacuation time of lumpsucker eggs. The ogival stomach evacuation model used in our study fitted the experimental data well, which can be explained by the process of egg digestion: once the egg chorion cracks and gastric fluids enter the eggs, egg contents are rapidly evacuated from the stomach. The average stomach evacuation time for lumpsucker eggs $(\sim 10 \mathrm{~h})$ is similar to earlier findings for other food eaten by smaller crabs in the size range of 70 to $90 \mathrm{~mm}$ CL (Pavlova 2009). The estimated stomach evacuation time of Pavlova (2009) relates to a temperature of $6^{\circ} \mathrm{C}$, while the temperature was $\sim 3.4^{\circ} \mathrm{C}$ at the spawning areas that we studied during the first weeks of the spawning season in 2003. Because of the rise in temperature up to $\sim 7^{\circ} \mathrm{C}$ (Hallfredsson \& Pedersen 2009) during the spawning season, which ended on July 5 in the consumption model used here, we did not attempt to include the effect of temperature on stomach evacuation rate in the consumption modelling.

The feeding periodicity of red king crab could have influenced the results of our field-based stomach analysis. If the period of most intensive feeding does not match the sampling period, consumption could be either over- or underestimated. Two peaks are observed in the daily feeding cycle of mature male crabs in Bristol Bay in the Bering Sea, with the most 

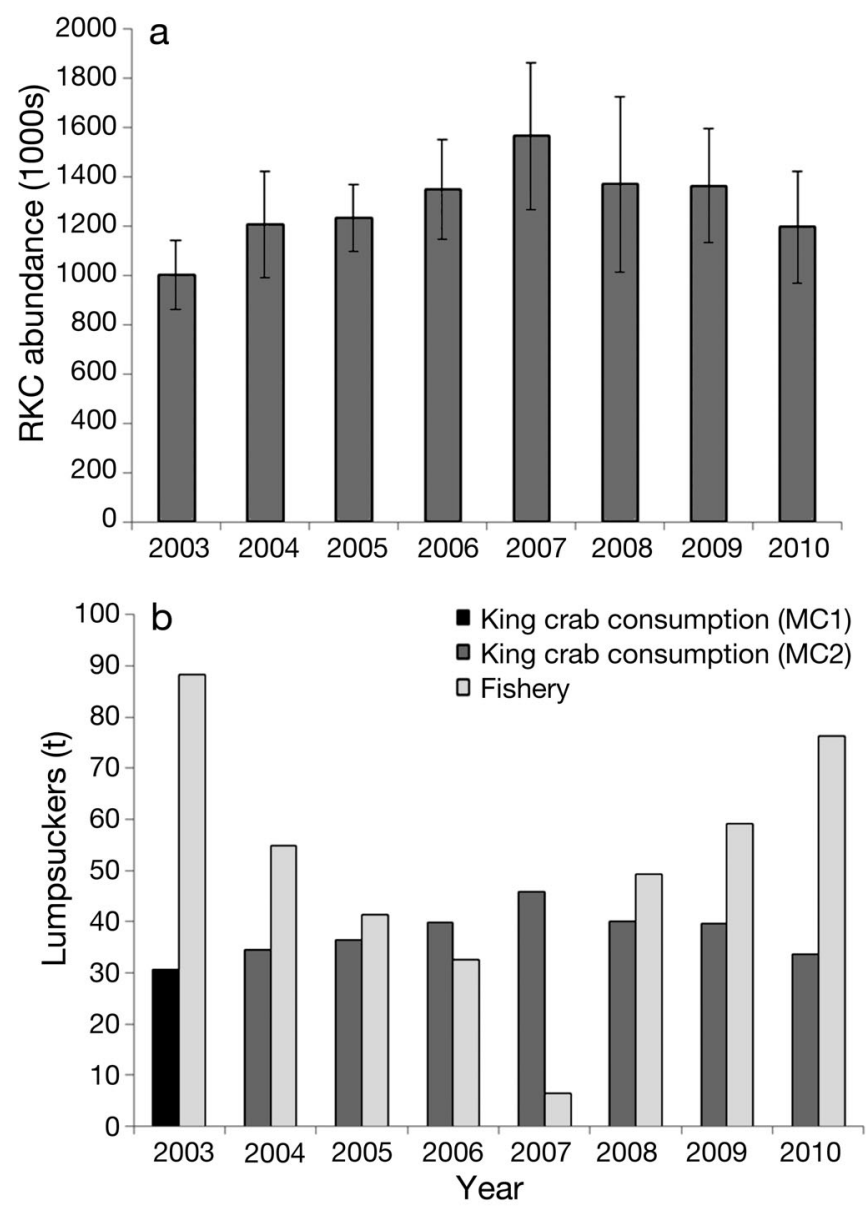

Fig. 6. (a) Red king crab (RKC) population abundance (>70 mm CL; mean \pm SE) in Varanger Fjord in 2003-2010 (data from the Institute of Marine Research). (b) Consumption of lumpsucker eggs by red king crab from Monte Carlo (MC) estimations by MC1 (black bar) and MC2 (grey bar) are shown together with landings of roe (light grey bar) from fisheries in Varanger Fjord in 2003-2010 (data from the Norwegian Fishermen's Sales Organisation). MC1 is based on input data from 2003. MC2 is based on the same input data from 2003 for all parameters, except from the abundance of red king crab, which is replaced by the time series for the period 2004-2010 shown in (a)

active feeding period being recorded at night (Tarverdieva 1978). This is in accordance with the finding that crustaceans feed at night (Hill 1976, Chatterton \& Williams 1994). Nevertheless, red king crabs in our study area do not display a diel rhythm in feeding activity during the polar summer, when light levels are relatively high at night (Jørgensen et al. 2007). The wide range in the number of eggs found in stomachs also suggests that feeding periodicity is low at the population level. Since food consumption estimates are less sensitive to low frequency of sampling at low temperatures (Finstad 2005) and the average temperature in the area of study in 2003 was around $3.4^{\circ} \mathrm{C}$, it is unlikely that low frequency of sampling and feeding periodicity introduced a heavy bias.

By chasing away the lumpsucker male guarding the eggs, the invasive red king crab may enhance predation from other predators, such as sea urchins Strongylocentrotus droebachiensis. Moreover, lack of parental care may result in total loss of the egg mass (Goulet et al. 1986). We observed damage to unconsumed eggs both in the field and in laboratory experiments. Prey mortality due to damage caused by crab feeding activity was also reported in feeding experiments with scallops (Jørgensen 2005) and sea urchins (Pavlova 2009). Similar damaging feeding behaviour was observed experimentally in Chinese mitten crabs Eriocheir sinensis feeding on salmonid eggs (C. Culver pers. comm.). The total egg loss due to king crab feeding activity is thus much greater than the estimates of direct consumption offered here. Consumption may be underestimated because juvenile crabs were not included in this study and stomach samples in field were collected early in the spawning season. Since the lumpsucker is a batch spawner and eggs can be available for $\sim 3 \mathrm{mo}$, it is likely that egg density is higher in the middle of the spawning season, which may lead to a higher FO and average number of eggs in stomachs than found in this study. Juveniles are found in shallow waters all year round, and feed on lumpsucker eggs (Sokolov \& Milyutin 2006), but since there are no estimates available for the population size of juveniles, we had no input data for MC estimation of their consumption. Aggregations of juvenile king crabs may seriously damage both their own food resources and those of fish in benthic communities (Pavlova 2008).

If some crabs specialise in feeding on lumpfish eggs, this will contribute to large variability in egg consumption among individuals. The lack of area and sex effects and the wide range in the number of eggs found in crab stomachs suggest that individual specialist feeding behaviour may occur. In support of this, feeding selectivity was reported in juvenile king crabs (aged 3-4 yr, carapace width 47-63 mm) (Britayev et al. 2010) and in experimental work on immature crabs which preferred to feed on brittle stars among all echinoderms (Pavlova 2009). Individual specialisation, whereby the feeding niche of an individual is substantially narrower than the population niche, occurs in many predators utilising a broad array of taxa, if individual specialist feeding behaviour occurs, an invader can profoundly affect the ecological and evolutionary dynamics of a prey population (Bolnick et al. 2003). However, the red king crab 
is commonly classified as an opportunistic feeding crustacean (Cunningham 1969, Jewett \& Feder 1982, Jørgensen \& Primicerio 2007). This feeding behaviour is common amongst invasive crustaceans (Hänfling et al. 2011). Although it was suggested that generalist feeding behaviour of the red king crab hinders the elimination of particular prey species (Britayev et al. 2010), it can cause declines in prey populations and thereby have a negative effect on fisheries of commercially exploited species like the lumpfish.

As the estimated egg consumption by king crab in 2003 was one-third of the roe catch, and avoiding overexploitation is considered important for the development of the lumpsucker stock (Albert et al. 2002), further fisheries management should take into account the significant contribution of crab predation to egg mortality. Ecosystem-based fisheries management and the precautionary approach state that the lack of scientific certainty should not be used as a reason for postponing cost-effective measures to prevent environmental degradation (Garcia et al. 2003). Studies of ecological effects of the invasive red king crab are demanding and time-consuming. The attempt to prevent further spread of this invasive species should be intensified despite the scientific uncertainty about the species' ecological effects.

Our primary objectives were to study the feeding behaviour of the red king crab at lumpsucker spawning sites and to estimate its consumption of lumpsucker eggs. Observations in the field demonstrated that the male lumpsucker guardian is unable to prevent the crab from feeding on his eggs. Stomach analysis showed that egg predation is not affected by sex or lumpsucker spawning area. Further, mortality due to crab predation was higher than consumption estimates because the crabs destroy and expose eggs to other predators during feeding activity. The increased egg mortality caused by the invasive red king crab may hamper lumpsucker recruitment and thereby also the recovery of the stock.

Acknowledgements. We thank the crew of MS 'Leif Roald' and RV 'Johan Ruud', Subsea Nor ROV pilot and diver J. E. Jenssen, diver O. Jerijærvi, diver B. Seim and A. M. Hjelseth at the Institute of Marine Research.

\section{LITERATURE CITED}

Albert OT, Torstensen E, Bertelsen B, Jonsson ST, Pettersen IH, Holst JC (2002) Age-reading of lumpsucker (Cyclopterus lumpus) otoliths: dissection, interpretation and comparison with length frequencies. Fish Res 55: 239-252
Anisimova N, Berenboim B, Gerasimova O, Manushin I, Pinchukov M (2005) On the effect of red king crab on some components of the Barents Sea ecosystem. In: Shibanov V (ed) Ecosystem dynamics and optimal longterm harvest in the Barents Sea Fisheries. Proc 11th Russian-Norwegian Symp. IMR/PINRO Joint Report Series, Bergen, p 298-306

Bajkov AD (1935) How to estimate the daily food consumption of fish under natural conditions. Trans Am Fish Soc 65:288-289

Bax NJ (1998) The significance and prediction of predation in marine fisheries. ICES J Mar Sci 55:997-1030

Blacker RW (1983) Pelagic records of the lumpsucker, $\mathrm{Cy}$ clopterus lumpus L. J Fish Biol 23:405-417

> Bolnick DI, Svanback R, Fordyce JA, Yang LH, Davis JM, Hulsey CD, Forister ML (2003) The ecology of individuals: incidence and implications of individual specialization. Am Nat 161:1-28

Breder CM, Rosen DR (1966) Modes of reproduction in fishes: how fishes breed. Natural History Press, New York, NY

Britayev TA, Rzhavsky AV, Pavlova LV, Dvoretskij AG (2010) Studies on impact of the alien red king crab (Paralithodes camtschaticus) on the shallow water benthic communities of the Barents Sea. J Appl Ichthyol 26: 66-73

Bromley PJ (1994) The role of gastric evacuation experiments in quantifying the feeding rates of predatory fish. Rev Fish Biol Fish 4:36-66

> Chatterton TD, Williams BG (1994) Activity patterns of the New Zealand cancrid crab Cancer novaezelandiae (Jacquinot) in the field and laboratory. J Exp Mar Biol Ecol 178:261-274

Collins MAJ (1976) The lumpfish (Cyclopterus lumpus L.) in Newfoundland waters. Can Field Nat 90:64-67

Collins MAJ (1978) Experiments on the hatching period of the eggs of the lumpfish Cyclopterus lumpus L. in Newfoundland waters. Nat Can 105:169-171

Cox P, Anderson BA (1922) A study of lumpfish (Cyclopterus lumpus L.). Contributions to Canadian Biology 1:3-20

Cristo M (2001) Gut evacuation rates in Nephrops norvegicus (L.,1758): laboratory and field estimates. Sci Mar 65:341-346

Cristo M, Castro M (2005) Field estimation of daily ration of Norway lobster (Nephrops norvegicus) in the south of Portugal. NZ J Mar Freshw Res 39:485-491

Cunningham DT (1969) A study of the food and feeding relationships of the Alaskan king crab Paralithodes camtschatica. MSc thesis, San Diego State University

Davenport J (1985) Synopsis of biological data on the lumpsucker, Cyclopterus lumpus (Linnaeus, 1758). FAO, Rome

> DeBlois E, Leggett WC (1993) Match/mismatch between the abundance of marine fish eggs and invertebrate predators: An analysis of Calliopius laeviusculus (Amphipoda: Gammaridae) population growth relative to the seasonal spawning cycle of capelin (Mallotus villosus). Can J Fish Aquat Sci 50:2581-2590

Donaldson WE, Byersdorfer SE (2005) Biological field techniques for lithodid crabs. Alaska Sea Grant College Program. University of Alaska Fairbanks, Fairbanks, AK

dos Santos J, Jobling M (1991) Factors affecting gastric evacuation in cod, Gadus morhua L., fed single meals of natural prey. J Fish Biol 38:697-713

Eggers DM (1977) Factors in interpreting data obtained by 
diel sampling of fish stomachs. J Fish Res Board Can 34: 290-294

Eggers DM (1979) Some recent methods for estimating foodconsumption by fish - reply. J Fish Res Board Can 36: 1018-1019

Elliott JM, Persson L (1978) Estimation of daily rates of foodconsumption for fish. J Anim Ecol 47:977-991

- Finstad AG (2005) Effect of sampling interval and temperature on the accuracy of food consumption estimates from stomach contents. J Fish Biol 66:33-44

Garcia SM, Zerbi A, Aliaume C, Do Chi T, Lasserre G (2003) The ecosystem approach to fisheries. Issues, terminology, principles, institutional foundations, implementation and outlook. FAO Fisheries Technical Paper no. 443. FAO, Rome

Goulet D, Green JM (1988) Reproductive success of the male lumpfish (Cyclopterus lumpus L.) (Pisces: Cyclopteridae): evidence against female mate choice. Can J Zool 66:2513-2519

Goulet D, Green JM, Shears TH (1986) Courtship, spawning, and parental care behavior of the lumpfish, $C y$ clopterus lumpus L., in Newfoundland. Can J Zool 64: 1320-1325

Gudimov AV, Gudimova EN, Pavlova LV (2003) Effect of the red king crab Paralithodes camtschaticus on the Murmansk coastal macrobenthos: the first estimates using sea urchins of the genus Strongylocentrotus as an example. Dokl Biol Sci 393:539-541

Hallfredsson EH, Pedersen T (2009) Effects of predation from juvenile herring (Clupea harengus) on mortality rates of capelin (Mallotus villosus) larvae. Can J Fish Aquat Sci 66:1693-1706

Hänfling B, Edwards F, Gherardi F (2011) Invasive alien Crustacea: dispersal, establishment, impact and control. BioControl 56:573-595

Haugan TA (2004) Bunnsamfunn og næringsvalg hos kongekrabbe, Paralithodes camtschaticus (Tilesius, 1815), på noen lokaliteter in Finnmark. MSc thesis, University of Tromsø

- Hill BJ (1976) Natural food, foregut clearance-rate and activity of crab Scylla serrata. Mar Biol 34:109-116

> Holst JC (1993) Observations on the distribution of lumpsucker (Cyclopterus lumpus, L) in the Norwegian Sea. Fish Res 17:369-372

Hood GM (2010) PopTools version 3.2.3. Available at www.poptools.org

$>$ Jewett SC, Feder HM (1982) Food and feeding-habits of the king crab Paralithodes camtschatica near Kodiak Island, Alaska. Mar Biol 66:243-250

> Jobling M (1981) Mathematical models of gastric emptying and the estimation of daily rates of food consumption for fish. J Fish Biol 19:245-257

$>$ Jørgensen LL (2005) Impact scenario for an introduced decapod on Arctic epibenthic communities. Biol Invasions 7: 949-957

> Jørgensen LL, Primicerio R (2007) Impact scenario for the invasive red king crab Paralithodes camtschaticus (Tilesius, 1815) (Reptantia, Lithodidae) on Norwegian, native, epibenthic prey. Hydrobiologia 590:47-54

> Jørgensen T, Løkkeborg S, Fernö A, Hufthammer M (2007) Walking speed and area utilization of red king crab (Paralithodes camtschaticus) introduced to the Barents Sea coastal ecosystem. Hydrobiologia 582:17-24

Kudryavtseva OY, Karamushko OV (2002) Biology of the lumpfish Cyclopterus lumpus during reproduction in the
Murman nearshore zone. J Appl Ichthyol 42:309-313

> Maynou F, Cartes JE (1997) Field estimation of daily ration in deep-sea shrimp Aristeus antennatus (Crustacea: Decapoda) in the western Mediterranean. Mar Ecol Prog Ser 153:191-196

M'Intosh WC (1886) On the paternal instincts of Cyclopterus lumpus L. Ann Mag Nat Hist 18:81-84

McLaughlin PA, Hebard JF (1961) Stomach contents of the Bering Sea king crab. Bull Int North Pac Fish Comm 5: 5-8. Available at www.afsc.noaa.gov/Publications/Crab _History/docs/1961_McLaughlin_Hebard_INPFC_Bulletin5 _Stomach_Contents_of_the_BS_King_Crab_searchable.pdf

Molnar JL, Gamboa RL, Revenga C, Spalding MD (2008) Assessing the global threat of invasive species to marine biodiversity. Front Ecol Environ 6:485-492

Munoz RC, Currin CA, Whitfield PE (2011) Diet of invasive lionfish on hard bottom reefs of the Southeast USA: insights from stomach contents and stable isotopes. Mar Ecol Prog Ser 432:181-193

> Olson RJ, Boggs C (1986) Apex predation by yellofin tuna (Thunnus albacares): independent estimates from gastric evacuation and stomach contents, bioenergetics, and cesium concentrations. Can J Fish Aquat Sci 43: 1760-1775

> Orlov YI, Ivanov BG (1978) On the introduction of the Kamchatka king crab Paralithodes camtschatica (Decapoda: Anomura: Lithodidae) into the Barents Sea. Mar Biol 48: 373-375

Orlov YI, Karpevich AF (1965) On the introduction of the commercial crab Paralithodes camtschaticus (Tilesius) into the Barents Sea. ICES J Mar Sci 156:59-61

> Oug E, Cochrane S, Sundet JH, Norling $\mathrm{K}$, Nilsson HC (2010) Effects of the invasive red king crab (Paralithodes camtschaticus) on soft-bottom fauna in Varangerfjorden, northern Norway. Mar Biodivers 41:467-479

Park K (2004) Assessment and management of invasive alien predators. Ecol Soc 9 (2):12. Available at www.ecologyandsociety.org/vol9/iss2/art12

Pavlova LV (2008) Effect of juvenile red king crabs on zoobenthos in Kola Bay (Barents Sea). Dokl Biol Sci 393: 281-283

Pavlova LV (2009) Estimation of foraging on the sea urchin Strongylocentrotus droebachiensis (Echinoidea: Echinoida) by the red king crab Paralithodes camtschaticus (Malacostraca: Decapoda) in coastal waters of the Barents Sea. Biol Morya 35:288-295

Pimentel D, Lach L, Zuniga R, Morrison D (2000) Environmental and economic costs of nonindigenous species in the United States. Bioscience 50:53-65

Russell FS (1976) The eggs and planktonic stages of British marine fishes. Academic Press, London

Sardà F, Valladares FJ (1990) Gastric evacuation of different foods by Nephrops norvegicus (Crustacea: Decapoda) and estimation of soft tissue ingested, maximum food intake and cannibalism in captivity. Mar Biol 104:25-30

Sokolov VI, Milyutin DM (2006) Some behavioral features of the red king crab (Paralithodes camtschaticus) at the coastal zone of the Barents Sea. Zool Zh 85:28-37

Sundet JH, Hjelseth AM (2010) Seasonal depth distribution of the red king crab (Paralithodes camtschaticus) in Varangerfjorden, northern Norway. In: Kruse GH, Eckert GL, Foy RJ, Lipcius RN, Sainte-Marie B, Stram DL, Woodby D (eds) Biology and management of exploited crab populations under climate change. 25th Lowell Wakefield Fisheries Symp. Alaska Sea Grant College 
Program, University of Alaska Fairbanks, Fairbanks, AK

Sundet JH, Rafter EE, Nilssen EM (2000) Sex and seasonal variation in the stomach content of the red king crab, Paralithodes camtschaticus in the southern Barents Sea. In: Klein JCV, Schram FR (eds) Biodiversity crisis and Crustacea, Book 12. Balkema Publishers, Leiden

Sunnanå K (2004) Rognkjeks [Lumpsucker] In: Michalsen $\mathrm{K}$ (ed) Havets ressurser (Ocean resources). Fisken og havet no. 1-2004. Institute of Marine Research, Bergen, p 128-130. Available at www.imr.no/filarkiv/2004/03/5.3 _Rognkjeks.pdf/nb-no/

Sunnanå K (2006) Rognkjeks [Lumpsucker]. In: Svåsand T, Boxaspen K, Dahl E, Jørgensen LL (eds) Kyst og havbruk (The coastal zone and aquaculture). Fisken og havet no. 2-2006. Institute of Marine Research, Bergen, p 72-74. Available at www.imr.no/filarkiv/2007/03/2.4_Rognkjeks .pdf/nb-no/

Sunnanå K (2009) Rognkjeks od rognkall [Lumpsucker]. In: Agnalt AL, Bakketeig IE, Haug T, Knutsen JA, Opstad I (eds) Kyst og havbruk (The coastal zone and aquaculture). Fisken og havet no. 1-2009. Institute of Marine Research, Bergen, p 95-96. Available at www.imr.no/

Editorial responsibility: Antony Underwood, Sydney, New South Wales, Australia
filarkiv/kyst_og_havbruk_2009/Kap_2.4.pdf/nb-no/ Sunnanå K (2011) Rognkjeks/-kall [Lumpsucker]. In: Agnalt AL, Rasmussen $\mathrm{T}$ (eds) Havforskningsrapporten 2011: ressurser, miljø og akvakultur på kysten og i havet. Fisken og havet no. 1-2011. Institute of Marine Research, Bergen, p 137. Available at www.imr.no/filarkiv/2011/ 04/havforskningsrapporten2011.pdf/nb-no/

Tarverdieva MI (1978) Diurnal feeding rhythm of the king crab Paralithodes camtschatica. Biol Morya 3:91-95

> Vasconcelos P, Monteiro CC, Santos MN, Gaspar MB (2004) First record of the lumpfish (Cyclopterus lumpus Linnaeus, 1758) off the Algarve coast (southern Portugal): southward extension of the species distributional range. J Appl Ichthyol 20:159-160

> Waddington K (2008) Variation in evacuation rates of different foods skew estimates of diet in the western rock lobster Panulirus cygnus. Mar Freshw Res 59:347-350

- Wlodarczyk E, Durbin AG, Durbin EG (1992) Effect of temperature on lower feeding thresholds, gut evacuation rate, and diel feeding behavior in the copepod Acartia hudsonica. Mar Ecol Prog Ser 85:93-106

Zhitenev AN (1970) Ecological and morphological affinities of the lumpsucker. Vopr Ikhtiol 10:77-84

Submitted: January 13, 2012; Accepted: June 28, 2012 Proofs received from author(s): November 9, 2012 